Evren GÜNEN1 ${ }^{1}$

Ahmet ALTINDIŞLi²
${ }^{1}$ Ege Üniversitesi,Ödemiş Meslek Yüksek Okulu, 35750, Ödemiş-Izmir / Türkiye

${ }^{2}$ Ege Üniversitesi, Ziraat Fakültesi, Bahçe Bitkileri Bölümü, 35100, İzmir / Türkiye

sorumlu yazar: evren.gunen@ege.edu.tr

Anahtar Sözcükler:

Cabernet Sauvignon, asma, anaç, aşı kombinasyonu, tüplü fidan

Key Words:

Cabernet Sauvignon, grape, rootstock, graft combination, tube sapling

\section{Cabernet Sauvignon Üzüm Çeşidinin Bazı Amerikan Asma Anaçları ile Aşı Kombinasyonlarının Örtü Altı ve Açıkta Yetiştiricilik Koşullarında Tüplü Fidan Performanslarının Değerlendirilmesi}

\author{
An Assesment of Tube Sapling Performance of Graft \\ Combinations of Cabernet Sauvignon Grape Variety with \\ Some American Rootstocks Under Greenhouse and Open \\ Field Conditions
}

Alınıs (Received): 19.02.2015 Kabul tarihi (Accepted): 09.11.2016

\section{ÖZET} raştırmada Ege bölgesinde yaygınlaşan kırmızı şaraplık üzüm çeşitlerinden
olan Cabernet Sauvignon'un yine aynı bölgede yaygın olarak kullanılan $99 R$
ve $110 R$ ile son yıllarda kullanımı gittikçe artan 1103P amerikan asma
anaçlarının aşı kombinasyonları kullanılmıştır. Aşı kombinasyonlarına ait aşılı
çelikler kaynaştırma odasında kallus gelişimleri tamamlandıktan sonra tüplere
aktarılmış ve tüplü fidanlar örtü altında ve açıta yetiştiricilik koşullarında
vejetasyon gelişimi sonuna kadar bakılmıştır. Vejetaston dönemi sonunda
tüplü fidanlar 21 farklı fidan değerlendirme kriterine göre analiz edilmiş ve
performans farklılıkları ortaya konularak bölgemizde giderek artmakta olan
şaraplık üzüm üretimine çoğaltım materyali sağlayan fidancılara ve üreticilere
ışı tutması amaçlanmıştır. Çalışma sonucunda Cabernet Sauvignon/1103P aşı
kombinasyonunun hem örtü altında hem de açıkta yetiştiricilik koşullarında her
iki yılda da fidan gelişim ve kalitesinin diğer kombinasyonlardan daha iyi
olduğu ortaya konmuştur. Sürgün odunlaşma düzeyi ve fidan randımanı gibi
önemli bazı kriterler konusunda örtü altı yetiştiricilik şartları açıkta
yetiştiriciliğe göre daha başarılı sonuçlar vermiştir.

\footnotetext{
ABSTRACT

$\mathbf{T}$ he materials used in this research include Cabernet Sauvignon, a widespread red wine grape variety in the Aegean region, and its graft combination with widely used R99 and R110 rootstocks as well as 1103P american rootstock, whose use has also increased in recent years. In the study, grafted rootstocks were kept and protected in a protected mainstreaming room up to the completion of callus formation and then transferred to tubes. Grafted tube saplings were kept in open field and greenhouse conditions until the end of the vegetation period and tube saplings were examined at the end of the vegetation period. At the end of vegetation period, tube seedlings were analyzed according to 21 different seedling evaluation and performance criteria and the differences were determined. The results of Cabernet Sauvignon / 1103P graft combination has demonstrated that the combination of seedling growth and quality during a period of two years both in the open field and greenhouse culture conditions was better than the other combinations. The breeding conditions in the greenhouse cultivation showed more successful results as regards some important criteria such as the level of shoot lignification and sapling performance.
} 


\section{Giriş}

Tüm Dünya'da olduğu gibi ülkemiz topraklarının da filoksera zararlısı ile bulaşık olması sebebi ile dayanıklı anaç kullanımı zorunlu hale gelmiş ve amerikan asma anaçları artık bağcılığımız açısından vazgeçilmez olmuştur (IItter ve ark., 1984; Ecevit, 1991; Ergenoğlu ve Gürsoy, 1991).

Filoksera haricindeki bazı faktörler de yine bağlarımızı kendi kökleri üzerinde yetiştirebilmemize engel olmaktadır. Çelik ve ark. (1998) eğim, toprak derinliği, taban suyu, ana kaya ve benzeri sınırlayıcı faktörlerin de devreye girmesi ile anaç seçiminin önemine işaret etmişlerdir.

Çelik ve arkadaşlarının (2008) bildirdiği üzere 20042008 yılları arasındaki 5 yıllık süre zarfında toplam sertifikalı aşılı asma fidanı üretimimizin \% 40,7'si $(5,6$ milyon adet) fidan yurt dışından ithal edilmiş ve karşılığında 6,5 milyon avro döviz ödenmiştir.

Tüm olumsuz çevresel faktörlere karşı kullanımı yaygınlaşmış olan amerikan asma anaçlarının aşılama, kaynaştırma vb uygulamalar ile hem maliyet hem de işgücü ve zaman açısından olumsuz etkilerini azaltmak ve fidanlık kayıplarını engellemeye yönelik uyuşma ve kullanılacak üretim yöntemi konusunda yapılan çalışmaların önemi görülmektedir.

Bu araştırmada Cabernet Sauvignon/99R, Cabernet Sauvignon/110R, Cabernet Sauvignon/1103P aşı kombinasyonlarının aşılı tüplü fidan üretiminde tüplü fidanların açıkta ve yüksek plastik tünel altında üretilmeleri ve kendi tüplerinde ayni koşullarda bir yıl boyunca kalmalarının fidan randıman ve kalitesine etkileri araştırılmıştır.

\section{MATERYAL ve YÖNTEM}

Bu çalışma Ege Üniversitesi Ödemiş Meslek Yüksekokulu'nda 2004-2006 yılları arasında yürütülmüştür. Denemede bitkisel materyal olarak şaraplık üzüm çeşitlerinden Cabernet Sauvignon ile amerikan asma anaçlarından 99R, 110R, 1103P kullanılmıştır. Bitkisel materyal Manisa Bağcılık Araştırma İstasyonu'ndan temin edilmiştir.

Cabernet Sauvignon: Ege bölgesi gibi sıcak koşullarda çok başarılı sonuçlar veren kırmızı şaraplık çeşitlerin kalitesiyle en tanınanlarındandır. Salkımları uzun konik-silindirik, orta büyüklükte ve dolgundur. Üzüm taneleri küçük, yuvarlak ve kalın kabukludur. Yoğun mavi-gri puslu siyah renklidir. 1-3 çekirdek içerir.

Berl. x Rup. 99 R: Kuvvetli büyür, verimi iyidir. Üzerine aşılanan çeşidin, olgunlaştırmasını geciktirme eğilimindedir. Kurak bölgelerde aşılanması çok iyidir. Köklenme yeteneği ve filokseraya dayanması iyidir. \%17 kadar aktif kirece dayanabilirken, tuza dayanıksızdır. Kökleri, $45^{\circ}$ geotropizm açısına sahiptir.
Berl. x Rup. 110 R: Kuvvetli büyür ve üzerine aşıll çeşidin olgunlaşmasını geciktirir. \%17 aktif kirece dayanır. Kurağa çok dayanıklıdır. 99 R'ye göre daha verimli ve nemli topraklardan hoşlanır. Yerli çeşitlerle aşıya gelmesi ve afinitesi iyidir. Filokseraya dayanımı çok iyidir. Kökleri, toprakta yarı dik büyür. Köklenme yeteneği \%20yi geçmemektedir.

Berl x Rup 1103 Paulsen: Bu anaç kuvvetli olup alt katmanı nemli ve killi kireçli topraklara adaptasyonu iyidir. Kirece 99R ve 110R anaçları kadar dayanıklıdır (\%17-18). Gelişim kuvveti de 99R ile R 110'un arasında yer almaktadır. Topraktaki $0,6 \mathrm{~g} \mathrm{NaCl} / \mathrm{Kg}$ oranındaki tuza dayanmaktadır. Çok kurak topraklar için önerilmektedir. Köklenme ve aşı tutma oranı oldukça yüksektir

Anaç olarak kullanılacak çelikler boyları TS 4027'ye göre ayarlanmış ve yüzlü demetler haline getirilerek siyah polietilen torbalar içerisine konulmuştur. Torbalanmış çelikler $+1-+4^{\circ} \mathrm{C}$ ve $\% 90-95$ nemde aşının yapılacağı Mart ayına kadar saklanmıştır. Kalemler ise Winkler ve ark. (1974)'nın bildirdikleri gibi, bir yıllık dalların iyi odunlaşmış orta kııımlarından alınarak aynı koşullar altında depolanmıştır. Denemede masa başı omega aşı makinesi kullanıımıştır. Aşılanmış çelikler aşı yerinden su kaybını engellemek için parafinlenmişlerdir. İşlem sırasında aşı yerinin tamamen parafinle kaplanmasına ve parafin tabakasının 1-2 mm'den kalın olmamasına dikkat edilmiştir (Richards 1976, Neshev, K. ve Todor, K.H. 1978). Aşılı çelikler nemli talaş ortamında kasalar içinde kaynaştırmaya alınmıştır. Aşılı çelikler kaynaştırma ortamında sıcaklığı $25-28^{\circ} \mathrm{C}$ ve nemi $\% 85-$ 90 'da olacak şekilde 21 gün süreyle tutulmuşlardır. Süre boyunca sabit sıcaklık ve nem düzeyinde tutulan materyal zaman zaman havalandırlarak kof kallus oluşumu engellenmiştir (Çelik 1984). Kaynaştırma süresi sonunda aşılı çelikler alıştırmaya alınmışlardır. Daha sonra ikinci parafinleme yapılmış ve tüplere dikim işlemine geçilmiştir. Tüplerde kullanılan yetiştirme ortamı 2 kısım talaş, 1 kısım çiftlik gübresi, 1 kısım bahçe toprağı, $1 \mathrm{kısım} \mathrm{torf,} 1 \mathrm{kısım}$ perlit ve $1 \mathrm{kısım} \mathrm{çam}$ kabuğunun karışımından elde edilmiştir. Dikimleri tamamlanan tüpler açıkta ve yüksek plastik tünel altında deneme desenine uygun şekilde gruplanarak vegetasyon periyodunun sonuna kadar gerekli tüm kültürel işlemler yapılarak bakılmışlardır.

Fidanlarda değerlendirme kriterlerine göre ölçüm ve sayım gibi işlemlerin yapılabilmesi için yaprak dökümünden sonra Kasım ayı sonunda sökümler yapılarak değerlendirilmiştir.

\section{Fidanları Değerlendirmede Kullanılan Kriterler:}

Anaç kalınlığı, aşı noktası kalınlığı, kalem kalınlığı, aşı sürgünü boğum arası kalınlığı, kök uzunluğu, aşı sürgünü uzunluğu, aşı sürgünü odunlaşmış kısım uzunluğu, aşı kaleminden çıkan sürgün sayısı, koltuk 
sürgünü sayısı, sürgün gelişme düzeyi, aşı noktası kaynaşma düzeyi, kök gelişme düzeyi, kök sayısı, fidan yaş ağırlığı, fidan kuru ağırlığı, kök yaş ağırlığı, kök kuru ağırlığı, aşı sürgünü yaş ağırlığı, aşı sürgünü kuru ağırlığı, sürgün odunlaşma düzeyi, fidan randımanı. (Dimler ve ark., 1952; Fidan ve Eriş, 1972; Kacar, 1972 a; Kacar, 1972 b; Çelik, (1978); Kısmalı, (1978); Çelik,
(1982); Kısmalı ve Karakır, (1990); Çelik ve ark., (1991); Çelik ve Gider, (1991); Çelik ve ark., (1992) ve Çelik, (1993). Sürgün gelişme düzeyi, aşı noktası kaynaşma düzeyi ve kök gelişme düzeyi skala değerlerinde 4 en iyi, 1 en kötü değerlerdir. Çalışma yıllarına ait denemenin yürütüldüğü yerin bazı önemli iklim verileri çizelge 1 'de sunulmuştur.

Çizelge 1. İmir ili, Ödemiş ilçesi 2004-2005 yılı iklim verileri

Table 1. Climate data 2004/2005 Ödemiş/Izmir

\begin{tabular}{|c|c|c|c|c|c|c|c|c|c|c|c|c|c|}
\hline $\mathrm{YIL}$ & AYLAR & Oc. & Şub. & Mart & Nis. & May. & Haz. & Tem. & Ağu. & Eyl. & Ek. & Kas. & Ar. \\
\hline \multirow{4}{*}{ চ্் } & Max. Sıcaklık & 18 & 23 & 25 & 30 & 31 & 37 & 39 & 40 & 39 & 32 & 30 & 20 \\
\hline & Min. Sıcaklık & -5.8 & -5.2 & -3.3 & 0.6 & 7.0 & 12 & 14.4 & 13.2 & 8.0 & 9.5 & -3.3 & -3.9 \\
\hline & Sıcaklık ort. & 7.0 & 8.0 & 11 & 15 & 19.5 & 25.5 & 28 & 27 & 23 & 19 & 12.6 & 9.0 \\
\hline & $\% \mathrm{Nem}$ & 80 & 74 & 67 & 70 & 63 & 54 & 51 & 54 & 58 & 66 & 73 & 77 \\
\hline \multirow{4}{*}{ 늉 } & Max. Sıcaklık & 20.6 & 18 & 24 & 31 & 35 & 37 & 40 & 36.8 & 37.5 & 30 & 25 & 25 \\
\hline & Min. Sıcaklık & -1.7 & -4.2 & -2.2 & -0.5 & 7.0 & 11 & 15 & 11 & 11.6 & 16 & -1.0 & -3.8 \\
\hline & Sicaklık ort. & 8.7 & 7.8 & 11 & 15 & 21 & 25 & 29 & 25 & 22.8 & 16 & 11 & 10 \\
\hline & $\% \mathrm{Nem}$ & 76 & 72 & 70 & 64 & 61 & 52 & 52 & 52 & 62 & 70 & 75 & 79 \\
\hline
\end{tabular}

Deneme deseni ve istatistik değerlendirme: Deneme tesadüf parselleri deneme desenine göre üç tekerrürlü ve her tekerrürde 20 fidan olacak şekilde düzenlenmiştir. Çalışmanın istatistik analizleri TARIST istatistik paket programı kullanılarak yapılmıştır (Açıkgöz ve ark, 1994). Sonuçlara varyans analizi yapılmış ve ortalamaların farklılıklarının değerlendirilmesinde LSD testi kullanılmıştır.

\section{ARAŞTIRMA BULGULARI ve TARTIŞMA}

Cabernet Sauvignon/99R, Cabernet Sauvignon/ 110R, Cabernet Sauvignon/1103P aşı kombinasyonları kullanılarak üretilen aşılı tüplü fidanların fidan randıman ve kalite kriterlerine ait sonuçlar tablolar halinde aşağıda sunulmuştur. Tüm aşı kombinasyonlarına ait tüplü fidanlarda örtü altı ve açıkta yetiştiricilik şartlarının anaç kalınlığı açısından her iki yılda da istatistiki düzeyde önemli bir etkiye sahip olmadığı saptanmıştır (Çizelge 2).

Çizelge 2. Cabernet Sauvignon üzüm çeşidi aşılanmış üç farklı anacın, açıkta ve örtü altında tüplü fidan üretiminin anaç kalınlığına etkisi $(\mathrm{mm})$.

Table 2. The effect of tube saplings of graft combinations belonging to cabernet sauvignon grape variety with three american rootstocks under greenhouse and open field conditions on rootstock thickness $(\mathrm{mm})$.

\begin{tabular}{crrrrrr}
\cline { 2 - 7 } & \multicolumn{3}{c}{ 1. yıl } & \multicolumn{3}{c}{ 2. yıl } \\
\cline { 2 - 7 } & Açıkta & Örtü Altı & $\begin{array}{c}\text { Ortam } \\
\text { Ort. }\end{array}$ & Açıkta & Örtü Altı & $\begin{array}{c}\text { Ortam } \\
\text { Ort. }\end{array}$ \\
\hline $99 \mathrm{R}$ & 10,57 & 9,83 & 10,20 & 8,44 & 10,56 & 9,50 \\
$110 \mathrm{R}$ & 9,33 & 10,60 & 9,97 & 8,33 & 9,00 & 8,67 \\
$1103 \mathrm{P}$ & 10,00 & 9,47 & 9,74 & 9,94 & 9,78 & 9,86 \\
\hline Anaç Ort. & 9,97 & 9,97 & & 8,90 & 9,78 \\
\hline
\end{tabular}

Ortam ort. $\angle S D \%$ : o.d., Anaç ort. $\angle S D \%$ \%:ö.d.

Açık ve örtü altında yetiştirilen tüplü fidanlarda tüm anaçların aşı kombinasyonlarına ait fidanlar için her iki yılda da aşı noktası kalınlığı ölçülmüş ve aralarındaki farklar istatistiki değerlendirmeler sonucunda önemsiz bulunmuştur. Aşı noktası kalınlıklarının ortalama değerleri karşılaş̧ıııılığında bu sonuca paralel olarak Çelik ve ark., (1992), Çelik ve Gider (1991) benzer gelişme gücüne sahip anaçlar arasında farklılığın önemli çıkmadığını belirtmişlerdir. (Çizelge 3).

Çizelge 3. Cabernet Sauvignon üzüm çeşidi aşılanmış üç farkıı anacın, açıkta ve örtü altında tüplü fidan üretiminin aşı noktası kalınlığına etkisi (mm).

Table 3. The effect of tube saplings of graft combinations belonging to cabernet sauvignon grape variety with three american rootstocks under greenhouse and open field conditions on grafting area thickness $(\mathrm{mm})$

\begin{tabular}{ccccccc}
\cline { 2 - 7 } & \multicolumn{3}{c}{1. yıl } & \multicolumn{3}{c}{2 yıl } \\
\cline { 2 - 7 } & Açıkta & Örtü Altı & $\begin{array}{c}\text { Ortam } \\
\text { Ort. }\end{array}$ & Açıkta Örtü Altı & $\begin{array}{c}\text { Ortam } \\
\text { Ort. }\end{array}$ \\
\hline $99 \mathrm{R}$ & 16,07 & 14,30 & 15,18 & 12,11 & 13,11 & 12,61 \\
$110 \mathrm{R}$ & 14,87 & 16,53 & 15,70 & 12,67 & 13,56 & 13,12 \\
$1103 P$ & 15,13 & 13,87 & 14,50 & 13,33 & 13,44 & 13,39 \\
\hline Anaç Ort. & 15,36 & 14,90 & & 12,70 & 13,37 \\
\hline
\end{tabular}

Ortam ort. LSD \%5: ö.d., Anaç ort. LSD \%5:ö.d.

Kalem kalınlığı açısından örtü altı ve açıkta yetiştiricilik şartları arasında istatistiki düzeyde önemli bir fark oluşmuştur. Kalem kalınlığında 1. yıl için açıkta yetiştiricilik şartlarının, 2. yılda ise örtü altı şartlarının öne çıkması tamamen tesadüfi seçilen anaç ve özdeş kalınlıktaki aşı kalemlerinin tesadüfi dağılımlarından kaynaklanmaktadır. Aşı başarısı için önemli olan anaçkalem kalınlıklarının aynı ya da mümkün olduğunca yakın olmasıdır. Yıllar arasındaki farklılığa rağmen tüm değerler TS 3981'de yer alan ve 1. Sınıf fidanın minimum anaç kalınlığı olan 7 mm'den kalındır. Kalem kalınlığı üzerinde her iki ortamda yapılan yetiştiricilikte elde edilen tüm aşı kombinasyonlarında farklı anaçların etkisinin istatistiki anlamda fark yaratmadığı belirlenmiştir (Çizelge 4). 
Çizelge 4. Cabernet Sauvignon üzüm çeşidi aşılanmış üç farklı anacın, açıkta ve örtü altında tüplü fidan üretiminin kalem kalınlığına etkisi (mm).

Table 4. The effect of tube saplings of graft combinations belonging to cabernet sauvignon grape variety with three american rootstocks under greenhouse and open field conditions on graft cutting thickness ( $\mathrm{mm}$ ).

\begin{tabular}{ccccccc}
\cline { 2 - 7 } & \multicolumn{3}{c}{1. yıl } & \multicolumn{3}{c}{2. yıl } \\
\cline { 2 - 7 } & Açıta & Örtü Altı & $\begin{array}{c}\text { Ortam } \\
\text { Ort. }\end{array}$ & Açıta Örtü Altı & $\begin{array}{c}\text { Ortam } \\
\text { Ort. }\end{array}$ \\
\hline $99 R$ & 11,97 & 11,03 & 11,50 & 10,06 & 11,44 & 10,75 \\
$110 R$ & 11,80 & 10,67 & 11,23 & 9,44 & 10,56 & 10,00 \\
$1103 P$ & 11,65 & 10,60 & 11,13 & 9,67 & 11,89 & 10,78 \\
\hline Anaç Ort. & $11,81 \mathbf{a}$ & $10,77 \mathbf{b}$ & & $9,72 \mathbf{b}$ & $11,30 \mathbf{a}$ \\
\hline
\end{tabular}

Ortam 1.yıl LSD \%1: 0,680, Anaç 1.yıl LSD \%5:0̈.d., Ortam 2.yıl LSD \%5:1,280, Anaç 2.yıl LSD \%5:0̈.d.

Aşı sürgünü boğum arası kalınlığı açısından tüm aşı kombinasyonları için açık ve örtü altında ölçümler yapılmış ve hem yetiştiricilik şartı hem de farklı anaçlar için aralarındaki farklar istatistikçe önemsiz bulunmuştur. (Çizelge 5). Kaşka ve Yılmaz (1974) çalışmalarında kullanılan anaç ve çeşidin gelişme kuvvetlerinin farklı olduğu durumlarda aşı sürgünü boğum arası kalınlıklarına etkili bir faktör olduğunu belirtirken, çalışmada kullanılan anaçlar benzer gelişme gücüne sahip olduklarından bu sonuç doğaldır.

Çizelge 5. Cabernet Sauvignon üzüm çeşidi aşılanmış üç farklı anacın, açıkta ve örtü altında tüplü fidan üretiminin aşı sürgünü boğum arası kalınlığına etkisi $(\mathrm{mm})$.

Table 5. The effect of tube saplings of graft combinations belonging to cabernet sauvignon grape variety with three american rootstocks under greenhouse and open field conditions on shoot internodium thickness ( $\mathrm{mm}$ ).

\begin{tabular}{ccccccc}
\cline { 2 - 7 } & \multicolumn{3}{c}{1 yıl } & \multicolumn{3}{c}{2 .yıl } \\
\cline { 2 - 7 } & Açıkta & Örtü Altı & $\begin{array}{c}\text { Ortam } \\
\text { Ort. }\end{array}$ & Açıkta & Örtü Altı & $\begin{array}{c}\text { Ortam } \\
\text { Ort. }\end{array}$ \\
\hline $99 \mathrm{R}$ & 4,23 & 3,60 & 3,92 & 3,44 & 3,56 & 3,50 \\
$110 \mathrm{R}$ & 4,20 & 7,20 & 5,70 & 3,44 & 3,67 & 3,56 \\
$1103 \mathrm{P}$ & 8,47 & 4,13 & 6,30 & 4,00 & 4,28 & 4,14 \\
\hline Anaç Ort. & 5,63 & 4,98 & & 3,63 & 3,84 & \\
\hline
\end{tabular}

Ortam $\angle S D$ \%5: ö.d., Anaç LSD \%5:ö.d.

Aşılı tüm anaç kombinasyonlarının kök uzunluğu örtü altı ve açıkta yapılan yetiştiricilikten araştırmanın ilk yılında istatistiki önemli düzeyde etkilenmiştir. Buna göre açıkta yetiştiricilik $442.85 \mathrm{~mm}$ ile a, örtü altı ise $303.80 \mathrm{~mm}$ ile b grubunu meydana getirmişlerdir. Çalışmanın ikinci yılı için Cabernet Sauvignon çeşidinden elde edilen tüplü fidanlarda farklı anaçların kök uzunluğu üzerine etkisinin istatistiki anlamda iki farklı grup oluşturduğu, 1103P ve 110R'nin (a), 99R'nin (b) gurubunda olduğu görülmüştür. Eroğlu tarafından 2014 yilında yapılan çalışmada 110R/Alphonse: 557 mm, 1103P/Alphonse: 617 mm kök uzunluğu sonuçları ile $1103 \mathrm{P}$ ve $110 \mathrm{R}$ anaçları aynı grupta yer almıştır (Çizelge 6).

Çizelge 6. Cabernet Sauvignon üzüm çeşidi aşılanmış üç farklı anacın, açıkta ve örtü altında tüplü fidan üretiminin kök uzunluğuna etkisi (mm).

Table 6. The effect of tube saplings of graft combinations belonging to cabernet sauvignon grape variety with three american rootstocks under greenhouse and open field conditions on root lenght ( $\mathrm{mm}$ ).

\begin{tabular}{ccccccc}
\cline { 2 - 7 } & \multicolumn{3}{c}{ 1.yıl } & \multicolumn{3}{c}{2 yıl } \\
\cline { 2 - 7 } & Açıkta & Örtü Altı $\begin{array}{c}\text { Ortam } \\
\text { Ort. }\end{array}$ Açıkta & Örtü Altı & $\begin{array}{c}\text { Ortam } \\
\text { Ort. }\end{array}$ \\
\hline 99R & 457,67 & 312,20 & 384,93 & 321,11 & 252,78 & $286,95 \mathbf{b}$ \\
$110 \mathrm{R}$ & 522,7 & 280,60 & 401,60 & 395,56 & 498,33 & $446,95 \mathbf{a}$ \\
$1103 P$ & 348,17 & 318,60 & 333,38 & 350,00 & 416,11 & $383,06 \mathbf{a}$ \\
\hline Anaç Ort. 442,85a & $303,80 \mathbf{b}$ & 355,56 & 389,07 & \\
\hline
\end{tabular}

Ortam 1.yıl LSD \%1: 77,44, Ortam 2.yıl LSD \%5: ö.d., Anaç 1.yıl LSD \%:0̈.d., Anaç 2.yıl LSD \%1:83,363

Farklı anaçlara aşıı tüplü Cabernet Sauvignon fidanlarının aşı sürgünü uzunlukları açık ve örtü altı yetiştiricilikten her iki yılda da istatistiki önemli düzeyde etkilenmediği görülmüştür. Anaçların aşı sürgünü uzunluğuna etkisi değerlendirildiğinde ikinci yılda istatistiki olarak önemli bulunmuştur. Bu sonuçlar Kara ve ark. (2011)nın çalışmasındaki değerler ile (1103P/Cabernet: $359.7 \mathrm{~mm}$ ) paraleldir. Çalışmanın ikinci yılında görülen sıcak kuru rüzgar gibi olumsuzluklardan 1103P anacı 99R ve $110 \mathrm{R}$ anaçlarına göre daha az etkilenmiştir (Çizelge 7).

Çizelge 7. Cabernet Sauvignon üzüm çeşidi aşılanmış üç farklı anacın, açıkta ve örtü altında tüplü fidan üretiminin aşı sürgünü uzunluğuna etkisi $(\mathrm{mm})$.

Table 7. The effect of tube saplings of graft combinations belonging to cabernet sauvignon grape variety with three american rootstocks under greenhouse and open field conditions on shoot lenght $(\mathrm{mm})$.

\begin{tabular}{cllllll} 
& \multicolumn{3}{c}{1. yıl } & \multicolumn{3}{c}{2 . yıl } \\
\cline { 2 - 7 } & Açıkta & Örtü Altı & $\begin{array}{c}\text { Ortam } \\
\text { Ort. }\end{array}$ & Açıkta & Örtü Altı Ortam Ort. \\
\hline $99 \mathrm{R}$ & 386,80 & 319,80 & 353,30 & 241,67 & 133,33 & $187,50 \mathbf{b}$ \\
$110 \mathrm{R}$ & 435,4 & 440,40 & 437,90 & 227,78 & 181,67 & $204,73 \mathbf{b}$ \\
$1103 \mathrm{P}$ & 253,3 & 430,9 & 333,10 & 293,56 & 266,89 & $280,23 \mathbf{a}$ \\
\hline Anaç Ort. & 358,50 & 397,03 & & 254,34 & 193,96 &
\end{tabular}

Ortam 1.yıl LSD \%5: ö.d., Anaç 1.yıl LSD \%5:Ö.d., Ortam 2.yıl LSD \%5: ö.d.,Anaç2.yII LSD \%5:71,546

Aşı sürgünü odunlaşmış kısım uzunlukları değerlendirildiğinde; örtü altı ve açıkta yetiştiricilik şartlarının etkisi her iki yılda da istatistiki düzeyde önemli bulunmamıştır. Cabernet Sauvignon aşılı tüplü fidanlarda farklı anaçların aşı sürgünü odunlaşmış kısım uzunluğu üzerindeki etkisinin ikinci yılda istatistiki anlamda önemli olduğu görülmektedir. $1103 \mathrm{P}$ anacı $232.61 \mathrm{~mm}$ ile a grubunu $99 \mathrm{R}$ ve $110 \mathrm{R}$ anaçları ise sırasıyla 130.84 ve $135.83 \mathrm{~mm}$ ile b gurubunu oluşturmaktadır. (Çizelge 8 ). 
Çizelge 8. Cabernet Sauvignon üzüm çeşidi aşılanmış üç farklı anacın, açıkta ve örtü altında tüplü fidan üretiminin aşı sürgünü odunlaşmış kısım uzunluğuna etkisi ( $\mathrm{mm}$ ).

Table 8. The effect of tube saplings of graft combinations belonging to cabernet sauvignon grape variety with three american rootstocks under greenhouse and open field conditions on shoot lignification lenght $(\mathrm{mm})$.

\begin{tabular}{ccccccc}
\cline { 2 - 7 } & \multicolumn{3}{c}{$1 . y ı l$} & \multicolumn{3}{c}{2. yıl } \\
\cline { 2 - 7 } & Açıkta & Örtü Altı & $\begin{array}{c}\text { Ortam } \\
\text { Ort. }\end{array}$ & Açıkta & Örtü Altı & $\begin{array}{c}\text { Ortam } \\
\text { Ort. }\end{array}$ \\
\hline 99R & 281,13 & 250,27 & 265,70 & 140,56 & 121,11 & $130,84 \mathbf{b}$ \\
$110 R$ & 407,50 & 307,10 & 357,30 & 93,33 & 178,33 & $135,83 \mathbf{b}$ \\
$1103 P$ & 192,20 & 361,00 & 276,60 & 208,33 & 256,89 & $232,61 \mathbf{a}$ \\
\hline Anaç Ort. & 293,61 & 306,12 & & 147,41 & 185,44 & \\
\hline Ottam
\end{tabular}

Ortam 1.yıl LSD \%5: ö.d., Anaç 1.yıl LSD \%5:Ö.d., Ortam 2.yıl LSD \%5: ö.d., Anaç 2.yII $L S D$ \%: $: 73,792$

Kök sayısı açısından değerlendirildiğinde; örtü altı ve açıkta yapılan yetiştiricilikler aralarında çalışmanın ilk yılı için iki farklı istatistik önemli düzey grubu oluşturmuşlardır. Bunlardan açık 33.78 adet/fidan ile $\mathbf{a}$, örtü altı ise 24.38 adet/fidan ile b grubunu meydana getirmişlerdir. İkinci yılda esen sıcak kuru rüzgarların etkisi açıkta yetiştiricilik şartlarını doğal olarak daha fazla etkileyerek, ilk yıl için istatistik anlamda önemli bir fark olarak ortaya çıkan sonucu olumsuz etkilemiştir. Cabernet Sauvignon aşılı tüplü fidanlarda kullanılan üç anacın oluşturdukları kök sayıları arasındaki farklar istatistik açısından önemli bulunmuştur. Illk yılda anaçlar; 1103P (43.33 adet/fidan) a, 99R (25.37 adet/fidan) b, 110R (18.53 adet/fidan) c grubunda sınıflanmışlardır. Bu fark çalışmanın ikinci yılında da benzer şekilde gözlemlenebilmiş ve en başarılı anaç olarak 1103P öne çıkmıştır. Çalışmamızın kök sayısı sonuçları; Sucu (2012) ve Eroğlu (2014)nun araştırmalarındaki fidan başına kök sayısı açısından bildirdikleri en başarılı anaç olan 1103P için ortalama 12 adet/fidan değerinden hayli yüksektir. (Çizelge 9).

Çizelge 9. Cabernet Sauvignon üzüm çeşidi aşılanmış üç farklı anacın, açıkta ve örtü altında tüplü fidan üretiminin kök sayısına etkisi (adet/fidan).

Table 9. The effect of tube saplings of graft combinations belonging to cabernet sauvignon grape variety with three american rootstocks under greenhouse and open field conditions on number of root (number/sapling).

\begin{tabular}{ccccccc}
\cline { 2 - 7 } & \multicolumn{3}{c}{$1 . y ı l$} & \multicolumn{3}{c}{$2 . y$ yıl } \\
\cline { 2 - 7 } & Açıkta & Örtü Altı & $\begin{array}{c}\text { Ortam } \\
\text { Ort. }\end{array}$ & Açıkta & Örtü Altı & $\begin{array}{c}\text { Ortam } \\
\text { Ort. }\end{array}$ \\
\hline $99 \mathrm{R}$ & 30,87 & 19,87 & $25,37 \mathbf{b}$ & 30,67 & 23,11 & $26,89 \mathbf{a b}$ \\
$110 \mathrm{R}$ & 20,00 & 17,07 & $18,53 \mathbf{c}$ & 13,67 & 17,78 & $15,73 \mathbf{b}$ \\
$1103 \mathrm{P}$ & 50,47 & 36,20 & $43,33 \mathbf{a}$ & 25,00 & 43,00 & $34,00 \mathbf{a}$ \\
\hline Anaç Ort. & $33,78 \mathbf{a}$ & $24,38 \mathbf{b}$ & & 23,11 & 27,96 & \\
\hline
\end{tabular}

Ortam 1.yıl LSD \%1:4, 102, Anaç 1.yıl LSD \%1:5,024, Ortam 2.yıI LSD \%: ö.d., Anaç 2.yII LSD \%: 14,319

Aşı kaleminden çıkan sürgün sayısı açısından yapılan değerlendirmede örtü altı ve açıkta yetiştiricilik şartları arasında ve anaçlar arasında her iki yıl için de istatistiki düzeyde önemli bir fark bulunmamıştır. (Çizelge 10).
Çizelge 10. Cabernet Sauvignon üzüm çeşidi aşılanmış üç farklı anacın, açıkta ve örtü altında tüplü fidan üretiminin aşı kaleminden çıkan sürgün sayısına etkisi (adet/fidan).

Table 10. The effect of tube saplings of graft combinations belonging to cabernet sauvignon grape variety with three american rootstocks under greenhouse and open field conditions on shoot number (number/sapling)

\begin{tabular}{ccccccc}
\cline { 2 - 7 } & \multicolumn{3}{c}{ 1.yıl } & \multicolumn{3}{c}{2. yıl } \\
\cline { 2 - 7 } & Açıkta & Örtü Altı & $\begin{array}{c}\text { Ortam } \\
\text { Ort. }\end{array}$ & Açıkta & Örtü Altı & $\begin{array}{c}\text { Ortam } \\
\text { Ort. }\end{array}$ \\
\hline $99 \mathrm{R}$ & 1,33 & 1,27 & 1,30 & 1,22 & 1,00 & 1,11 \\
$110 \mathrm{R}$ & 1,20 & 1,47 & 1,33 & 1,44 & 1,11 & 1,28 \\
$1103 \mathrm{P}$ & 1,07 & 1,27 & 1,17 & 1,28 & 1,22 & 1,25 \\
\hline Anaç Ort. & 1,20 & 1,34 & & 1,31 & 1,11 & \\
\hline Onyyyyyy
\end{tabular}

Ortam LSD \%: ö.d., Anaç LSD \%:ö.d.

Koltuk sürgünü sayısı üzerine çalışmanın her iki yılında da açık ve örtü altında yetiştiriciliğin ve farklı anaçların etkileri istatistikçe önemsiz bulunmuştur. (Çizelge 11).

Çizelge 11. Cabernet Sauvignon üzüm çeşidi aşılanmış üç farklı anacın, açıkta ve örtü altında tüplü fidan üretiminin koltuk sürgünü sayısına etkisi (adet/fidan).

Table 11. The effect of tube saplings of graft combinations belonging to cabernet sauvignon grape variety with three american rootstocks under greenhouse and open field conditions on number of secondary shoot (number/sapling).

\begin{tabular}{ccccccc}
\cline { 2 - 7 } & \multicolumn{3}{c}{ 1. yıl } & \multicolumn{3}{c}{ 2. yıl } \\
\cline { 2 - 7 } & Açıkta & Örtü Altı & $\begin{array}{c}\text { Ortam } \\
\text { Ort. }\end{array}$ & Açıkta & Örtü Altı & $\begin{array}{c}\text { Ortam } \\
\text { Ort. }\end{array}$ \\
\hline $99 \mathrm{R}$ & 0,40 & 0,40 & 0,40 & 0,44 & 0,44 & 0,44 \\
$110 \mathrm{R}$ & 0,60 & 0,27 & 0,43 & 0,78 & 0,44 & 0,61 \\
$1103 \mathrm{P}$ & 0,47 & 0,33 & 0,40 & 0,78 & 0,78 & 0,78 \\
\hline Anaç Ort. & 0,49 & 0,33 & & 0,67 & 0,55 \\
\hline
\end{tabular}

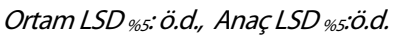

Sürgün gelişme düzeyi açısından değerlendirme yapıldığında örtü altı ve açıkta yapılan fidan yetiştiricilikleri arasında ilk yıla ait değerlerde istatistikçe önemli farklılık görülmüş ve iki grup oluşmuştur. Bunlardan örtü altı ortamı (3.29 puan; a grubu) açıkta yetiştiriciliğe (2.65 puan; b grubu) göre daha iyi sürgün gelişimi sağlamıştır. Farklı anaçların sürgün gelişme düzeyleri üzerindeki etkisinin istatistiki anlamda fark yaratmadığı görülmektedir (Çizelge 12).

Çizelge 12. Cabernet Sauvignon üzüm çeşidi aşılanmış üç farklı anacın, açıkta ve örtü altında tüplü fidan üretiminin sürgün gelişme düzeyine etkisi (1-4).

Table 12. The effect of tube saplings of graft combinations belonging to cabernet sauvignon grape variety with three american rootstocks under greenhouse and open field conditions on shoot growth level (1-4).

\begin{tabular}{ccccccc}
\cline { 2 - 7 } & \multicolumn{3}{c}{1 yıl } & \multicolumn{3}{c}{2. yıl } \\
\cline { 2 - 7 } & Açıkta & Örtü Altı & $\begin{array}{c}\text { Ortam } \\
\text { Ort. }\end{array}$ & Açıkta & Örtü Altı & $\begin{array}{c}\text { Ortam } \\
\text { Ort. }\end{array}$ \\
\hline $99 \mathrm{R}$ & 2,80 & 3,47 & 3,13 & 2,44 & 2,22 & 2,33 \\
$110 \mathrm{R}$ & 2,67 & 3,20 & 2,93 & 2,44 & 2,56 & 2,50 \\
$1103 \mathrm{P}$ & 2,47 & 3,20 & 2,83 & 2,83 & 3,44 & 3,14 \\
\hline Anaç Ort. & $2,65 \mathbf{b}$ & $3,29 \mathbf{a}$ & & 2,57 & 2,74 \\
\hline
\end{tabular}

Ortam 1.yıl $L S D$ \%5:0,345, Anaç 1.yıl LSD \%5:ö.d., Ortam 2.yıl LSD \%5: ö.d., Anaç 2.yıI $\angle S D$ \%:ö.d. 
Aşı kaynaşma düzeyleri skala değeri olarak tüm aşı kombinasyonlarında incelenmiş ve çalışmanın her iki yılı için anaç ve yetiştirme koşullarının aşı kaynaşma düzeyi açısından istatistik anlamda önem taşımadığı görülmüştür. Elde edilen değerler 1103P için; 3.4, 99R için; 3.5 ve $110 \mathrm{R}$ için; 3.5 skala değeri bildiren Köse ve ark. (2015) ile yakındır (Çizelge 13).

Çizelge 13. Cabernet Sauvignon üzüm çeşidi aşılanmış üç farklı anacın, açıkta ve örtü altında tüplü fidan üretiminin aşı kaynaşma skala düzeyine etkisi (1-4)

Table 13. The effect of tube saplings of graft combinations belonging to cabernet sauvignon grape variety with three american rootstocks under greenhouse and open field conditions on graft affinity scale degree (1-4).

\begin{tabular}{ccccccc}
\cline { 2 - 7 } & \multicolumn{3}{c}{ 1.yıl } & \multicolumn{3}{c}{ 2. yıl } \\
\cline { 2 - 7 } & Açıkta & Örtü Altı & $\begin{array}{c}\text { Ortam } \\
\text { Ort. }\end{array}$ & Açıkta & Örtü Altı & $\begin{array}{c}\text { Ortam } \\
\text { Ort. }\end{array}$ \\
\hline 99R & 3,53 & 3,60 & 3,57 & 3,00 & 3,22 & 3,11 \\
$110 \mathrm{R}$ & 3,20 & 3,60 & 3,40 & 3,00 & 3,89 & 3,45 \\
$1103 P$ & 3,67 & 3,73 & 3,70 & 3,61 & 3,78 & 3,70 \\
\hline Anaç Ort. & 3,47 & 3,64 & & 3,20 & 3,63 \\
\hline
\end{tabular}

Ortam LSD \%5: ö.d., Anaç LSD \%5:ö.d.

Kök gelişme düzeyi açısından çalışmanın ilk yılı için örtü altı ve açıkta yetiştirilen fidanlar arasındaki farklılıklar istatistik açısından önem arz etmiştir. İkinci yılda görülen olumsuzlukların sonuçları da kök sayısı kriterinin sonuçları ile paralellik göstermektedir. Kullanılan üç farklı anacın neden olduğu kök gelişme düzeylerindeki farklııklar da istatistik için önemli olarak hesaplanmıştır. Buna göre her iki yılda da Cabenrt Sauvignon/1103P aşı kombinasyonu en iyi kök gelişme düzeyine sahipken ikinciliği ilk yılda 99R, ikinci yılda ise 110R aşı kombinasyonları almıştır. (Çizelge 14).

Çizelge 14. Cabernet Sauvignon üzüm çeşidi aşılanmış üç farklı anacın, açıkta ve örtü altında tüplü fidan üretiminin kök gelişme düzeyine etkisi (1-4).

Table 14. The effect of tube saplings of graft combinations belonging to cabernet sauvignon grape variety with three american rootstocks under greenhouse and open field conditions on root growth level (1-4).

\begin{tabular}{|c|c|c|c|c|c|c|}
\hline & \multicolumn{3}{|c|}{ 1. yll } & \multicolumn{3}{|c|}{ 2. yıl } \\
\hline & Açıkta & Örtü Altı & $\begin{array}{c}\text { Ortam } \\
\text { Ort. }\end{array}$ & Açıkta & Örtü Altı & $\begin{array}{c}\text { Ortam } \\
\text { Ort. }\end{array}$ \\
\hline 99R & 3,67 & 3,20 & $3,43 \mathrm{ab}$ & 3,67 & 2,78 & $3,23 \mathbf{b}$ \\
\hline $110 \mathrm{R}$ & 3,40 & 2,93 & $3,17 \mathbf{b}$ & 3,11 & 3,56 & $3,34 \mathbf{a b}$ \\
\hline $1103 \mathrm{P}$ & 3,80 & 3,73 & $3,77 \mathbf{a}$ & 3,56 & 3,89 & $3,73 \mathbf{a}$ \\
\hline Anaç Ort. & $3,62 \mathbf{a}$ & $3,29 \mathbf{b}$ & & 3,45 & 3,41 & \\
\hline
\end{tabular}

Sürgün odunlaşma düzeyi açısından inceleme yapıldığında örtü altı ve açıkta yapılan yetiştiricilikler aralarında istatistik önemli farklılık çalışmanın her iki yılında da iki grup oluşturmuştur. Buna göre örtü altı yetiştiricilik koşulları, açıkta yetiştiricilik şartlarına göre sürgün odunlaşma düzeyi açısından daha başarılı bulunmuştur. Anaçların sürgün odunlaşma düzeyi üzerine etkisinin istatistiki anlamda önemli bir fark oluşturmadığı görülmüştür. (Çizelge 15).
Çizelge 15. Cabernet Sauvignon üzüm çeşidi aşılanmış üç farklı anacın, açıkta ve örtü altında tüplü fidan üretiminin sürgün odunlaşma düzeyine etkisi (1-4)

Table 15. The effect of tube saplings of graft combinations belonging to cabernet sauvignon grape variety with three american rootstocks under greenhouse and open field conditions on shoot lignification level (1-4).

\begin{tabular}{ccccccc}
\cline { 2 - 7 } & \multicolumn{3}{c}{1. yıl } & \multicolumn{3}{c}{2. yıl } \\
\cline { 2 - 7 } & Açıkta & Örtü Altı & $\begin{array}{c}\text { Ortam } \\
\text { Ort. }\end{array}$ & Açıkta & Örtü Altı & $\begin{array}{c}\text { Ortam } \\
\text { Ort. }\end{array}$ \\
\hline $99 \mathrm{R}$ & 3,00 & 3,20 & 3,10 & 2,78 & 3,78 & 3,28 \\
$110 \mathrm{R}$ & 2,73 & 2,93 & 2,83 & 2,33 & 3,89 & 3,11 \\
$1103 \mathrm{P}$ & 2,93 & 3,40 & 3,17 & 3,00 & 3,89 & 3,45 \\
\hline Anaç Ort. & $2,89 \mathbf{b}$ & $3,18 \mathbf{a}$ & & $2,70 \mathbf{b}$ & $3,85 \mathbf{a}$ \\
\hline
\end{tabular}

Ortam 1.yıl $L S D$ \%:0,252, Anaç 1.yıl LSD \%::0̈.d., Ortam 2.yıl LSD \%1:0,395, Anaç 2.yıl LSD \%5:0̈.d.

Kök yaş ağırlığı açısından değerlendirme yapıldığında örtü altı ve açıta yapılan yetiştiricilikler aralarında çalışmanın ilk yılı için iki farklı istatistikçe önemli düzey grubu oluşturmuşlardır. Bunlardan açık $14.38 \mathrm{~g}$ ile $\mathbf{a}$, örtü altı ise $8.33 \mathrm{~g}$ ile $\mathbf{b}$ grubunu meydana getirmişlerdir. Bu değerler Çelik ve ark. (1995)'in bulguları ile aynı aralıktadır. Fidanlarda farkı anaçların kök yaş ağırlığı üzerine etkisinin istatistiki anlamda önemli olmadığı görülmüştür (Çizelge 16).

Çizelge 16. Cabernet Sauvignon üzüm çeşidi aşılanmış üç farklı anacın, açıkta ve örtü altında tüplü fidan üretiminin kök yaş ağırlığına etkisi (g). Table 16. The effect of tube saplings of graft combinations belonging to cabernet sauvignon grape variety with three american rootstocks under greenhouse and open field conditions on root weight (g).

\begin{tabular}{ccccccc}
\cline { 2 - 7 } & \multicolumn{3}{c}{$1 . y ı l$} & \multicolumn{3}{c}{2 .yıl } \\
\cline { 2 - 7 } & Açıkta & Örtü Altı & $\begin{array}{c}\text { Ortam } \\
\text { Ort. }\end{array}$ & Açıkta & Örtü Altı & $\begin{array}{c}\text { Ortam } \\
\text { Ort. }\end{array}$ \\
\hline $99 \mathrm{R}$ & 12,80 & 7,39 & 10,10 & 10,96 & 5,00 & 7,98 \\
$110 \mathrm{R}$ & 16,36 & 7,08 & 11,72 & 7,87 & 9,70 & 8,79 \\
$1103 \mathrm{P}$ & 13,97 & 10,53 & 12,25 & 10,61 & 11,80 & 11,21 \\
\hline Anaç Ort. & $14,38 \mathbf{a}$ & $8,33 \mathbf{b}$ & & 9,81 & 8,83 \\
\hline
\end{tabular}

Ortam 1.yıl LSD \%5:4,768, Anaç 1.yıl LSD \%5:ö.d., Ortam 2.yıl LSD \%5: ö.d., Anaç 2.yıl LSD \%5:ö.d.

Aşı sürgünü yaş ağırılıkları değerlendirildiğinde, her iki yılda da açık ve örtü altı yetiştiricilikleri ve tüm anaçlar arasında istatistik açısından önemli bir fark gözlemlenmemiştir (Çizelge 17).

Çizelge 17. Cabernet Sauvignon üzüm çeşidi aşılanmış üç farklı anacın, açıkta ve örtü altında tüplü fidan üretiminin aşı sürgünü yaş ağırlığına etkisi (g).

Table 17. The effect of tube saplings of graft combinations belonging to cabernet sauvignon grape variety with three american rootstocks under greenhouse and open field conditions on shoot weight (g).

\begin{tabular}{ccccccc}
\cline { 2 - 7 } & \multicolumn{3}{c}{ 1. yıl } & \multicolumn{3}{c}{ 2. yıl } \\
\cline { 2 - 7 } & Açıkta & Örtü Altı & $\begin{array}{c}\text { Ortam } \\
\text { Ort. }\end{array}$ & Açıkta & Örtü Altı & $\begin{array}{c}\text { Ortam } \\
\text { Ort. }\end{array}$ \\
\hline $99 \mathrm{R}$ & 6,03 & 4,00 & 5,02 & 1,96 & 0,91 & 1,44 \\
$110 \mathrm{R}$ & 10,85 & 5,75 & 8,30 & 1,59 & 1,63 & 1,61 \\
$1103 P$ & 3,49 & 5,48 & 4,49 & 2,34 & 1,78 & 2,06 \\
\hline Anaç Ort. & 6,79 & 5,08 & & 1,96 & 1,44 \\
\hline
\end{tabular}

Ortam LSD \%5: ö.d., Anaç LSD \%5:Ö.d. 
Cabernet Sauvignon Üzüm Çeşidinin Bazı Amerikan Asma Anaçları ile Aşı Kombinasyonlarının Örtü Altı ve Açıkta Yetiştiricilik Koşullarında Tüplü Fidan Performanslarının Değerlendirilmesi

Fidanların yaş ağırlıkları ölçülmüş ve aralarındaki istatistiki değerlendirmeler sonucunda yetiştirme ortamı ve anaçların sebep olduğu farklar istatistik açısından önemsiz bulunmuştur (Çizelge 18).

Çizelge 18. Cabernet Sauvignon üzüm çeşidi aşılanmış üç farklı anacın, açıkta ve örtü altında tüplü fidan üretiminin fidan yaş ağırı̆̆ına etkisi $(\mathrm{g})$.

Table 18. The effect of tube saplings of graft combinations belonging to cabernet sauvignon grape variety with three american rootstocks under greenhouse and open field conditions on sapling weight $(g)$.

\begin{tabular}{ccccccc}
\cline { 2 - 7 } & \multicolumn{3}{c}{ 1.yıl } & \multicolumn{3}{c}{ 2. yıl } \\
\cline { 2 - 7 } & Açıkta & Örtü Altı & $\begin{array}{c}\text { Ortam } \\
\text { Ort. }\end{array}$ & Açıkta & Örtü Altı & $\begin{array}{c}\text { Ortam } \\
\text { Ort. }\end{array}$ \\
\hline 99R & 61,35 & 47,93 & 54,64 & 43,68 & 45,98 & 44,83 \\
$110 \mathrm{R}$ & 63,90 & 53,10 & 58,50 & 38,98 & 46,42 & 42,70 \\
1103 P & 56,80 & 50,49 & 53,64 & 48,64 & 52,57 & 50,61 \\
\hline Anaç Ort. & 60,68 & 50,51 & & 43,77 & 48,32 & \\
\hline
\end{tabular}

$\operatorname{Ortam} \angle S D \% 5:$ ö.d., Anaç $L S D$ \%::0̈.d.

Kök kuru ağırlıkları açısından örtü altı ve açık ortamları arasında çalışmanın birinci yılında istatistik anlamda önemli farklılıklar bulunmuş; açık ortamı 5.13 $\mathrm{g}$ ile a grubunu, örtü altı ise $3.18 \mathrm{~g}$ ile b grubunu oluşturmuşlardır. Anaçların kök kuru ağırlığına etkisi istatistik için önemsiz düzeyde kalmıştır. Hem ortam hem de anaç faktörlerinin kök yaş ağırlığı kriteri ile paralel sonuçlar vermesi fidan köklerinin su içerikleri ve kuru madde içerikleri açısından benzer olduklarını da göstermektedir (Çizelge 19).

Çizelge 19. Cabernet Sauvignon üzüm çeşidi aşılanmış üç farklı anacın, açıkta ve örtü altında tüplü fidan üretiminin kök kuru ağırlığına etkisi (g).

Table 19. The effect of tube saplings of graft combinations belonging to cabernet sauvignon grape variety with three american rootstocks under greenhouse and open field conditions on root dry weight (g).

\begin{tabular}{ccccccc}
\cline { 2 - 7 } & \multicolumn{3}{c}{ 1. yıl } & \multicolumn{3}{c}{2 yıl } \\
\cline { 2 - 7 } & Açıkta & Örtü Altı & $\begin{array}{c}\text { Ortam } \\
\text { Ort. }\end{array}$ & Açıkta & Örtü Altı & $\begin{array}{c}\text { Ortam } \\
\text { Ort. }\end{array}$ \\
\hline $99 \mathrm{R}$ & 4,68 & 2,75 & 3,71 & 2,61 & 1,43 & 2,02 \\
$110 \mathrm{R}$ & 6,57 & 2,99 & 4,78 & 2,07 & 3,31 & 2,69 \\
$1103 \mathrm{P}$ & 4,15 & 3,79 & 3,97 & 2,73 & 3,40 & 3,07 \\
\hline Anaç Ort. & $5,13 \mathbf{a}$ & $3,18 \mathbf{b}$ & & 2,47 & 2,71 \\
\hline
\end{tabular}

Ortam 1.yıl LSD \%5:1,955, Anaç 1.yıl LSD \%5:0̈.d., Ortam 2.yıl LSD \%5: ö.d., Anaç 2.yıl $L S D$ \%:ö.d.

Aşı sürgünü kuru ağırlığı çalışmanın her iki yılı boyunca açık ve örtü altında yapılan yetiştiricilik ve kullanılan her üç anaç açısından da istatistiki önemsiz bulunmuştur. (Çizelge 20).

Fidan kuru ağırlıkları üzerine ortam faktörünün ve anaçların etkisi incelenmiş, değerlendirmede istatistiki olarak önemli düzeyde bir ilişki bulunmamıştır. (Çizelge 21).
Çizelge 20. Cabernet Sauvignon üzüm çeşidi aşılanmış üç farklı anacın, açıkta ve örtü altında tüplü fidan üretiminin aşı sürgünü kuru ağırlığına etkisi (g).

Table 20. The effect of tube saplings of graft combinations belonging to cabernet sauvignon grape variety with three american rootstocks under greenhouse and open field conditions on shoot dry weight $(g)$.

\begin{tabular}{ccccccc}
\cline { 2 - 7 } & \multicolumn{3}{c}{1 yıl } & \multicolumn{3}{c}{2. yıl } \\
\cline { 2 - 7 } & Açıkta & Örtü Altı & $\begin{array}{c}\text { Ortam } \\
\text { Ort. }\end{array}$ & Açıkta & Örtü Altı & $\begin{array}{c}\text { Ortam } \\
\text { Ort. }\end{array}$ \\
\hline 99R & 3,20 & 2,13 & 2,67 & 0,82 & 0,38 & 0,60 \\
$110 \mathrm{R}$ & 5,91 & 3,25 & 4,58 & 0,54 & 0,94 & 0,74 \\
$1103 \mathrm{P}$ & 1,36 & 3,12 & 2,24 & 0,89 & 0,89 & 0,89 \\
\hline Anaç Ort. & 3,49 & 2,83 & & 0,75 & 0,74 \\
\hline
\end{tabular}

Ortam 1.yıl LSD \%5: ö.d., Anaç 1.yıl LSD \%5:ö.d.

Çizelge 21. Cabernet Sauvignon üzüm çeşidi aşılanmış üç farklı anacın, açıkta ve örtü altında tüplü fidan üretiminin fidan kuru ağırlığına etkisi (g).

Table 21. The effect of tube saplings of graft combinations belonging to cabernet sauvignon grape variety with three american rootstocks under greenhouse and open field conditions on sapling dry weight (g).

\begin{tabular}{ccccccc}
\cline { 2 - 7 } & \multicolumn{3}{c}{1. yıl } & \multicolumn{3}{c}{ 2. yıl } \\
\cline { 2 - 7 } & Açıkta & Örtü Altı & $\begin{array}{c}\text { Ortam } \\
\text { Ort. }\end{array}$ & Açıkta & Örtü Altı & $\begin{array}{c}\text { Ortam } \\
\text { Ort. }\end{array}$ \\
\hline 99R & 30,15 & 25,31 & 27,73 & 19,21 & 21,74 & 20,48 \\
$110 R$ & 31,11 & 29,25 & 30,18 & 17,90 & 23,06 & 20,48 \\
$1103 P$ & 26,31 & 25,48 & 25,90 & 21,92 & 26,36 & 24,14 \\
\hline Anaç Ort. & 29,19 & 26,68 & & 19,68 & 23,72 & \\
\hline
\end{tabular}

Ortam LSD \%5: ö.d., Anaç LSD \%5:Ö.d.

Üç farklı anaca aşılı tüplü Cabernet Sauvignon fidanlarının randımanları açık ve örtü altı ortamları kıyaslandığında birinci yıl için istatistik olarak önemli bir etkiye sahip olduğu saptanmıştır. Buna göre örtü altı ortamında yetiştirilen fidanların ortalama randımanları \%78.04 ile a grubunda yer alırlarken açıkta yetiştiricilikten elde edilen fidanların randımanları \% 71.69 ile b grubunda kalmışlardır. Çalışmanın ikinci yılında esen uzun süreli sıcak kuru rüzgarlar gibi olumsuz meteorolojik etkiler ile yıllar arasında da fidan randımanı açısından farklar oluşmuş, ikinci yıl fidan randıman değerleri ilk yılda tüm anaçlara ait randıman değerlerinden daha düşük olmuştur. Sonuçlar Baydar ve Ece (2005) tarafından Isparta koşullarında yapılan ve üç farklı çeşidin aşılandığı 1103P kombinasyonuna ait ortalama fidan randımanı değeri olan \%15.78'in çok üzerindedir. Narince çeşidi ile çalışan Sucu (2012) 1103P aşı kombinasyonunda \%50.5, 110R kombinasyonlarında ise \%68'lik değerler bildirmiştir. Bu değerler çalışmamızda elde ettiğimiz ortalamalara çok daha yakındır. Fidan randımanı üzerine üç farklı anaç kombinasyonunun etkisi de istatistiki değerlendirmeler sonucunda önemli bulunmuş ve çalışmanın her iki yılında da fidan randımanı açısından en başarılı anaç olarak 1103P bulunmuştur. (Çizelge 22). 
Çizelge 22. Cabernet Sauvignon üzüm çeşidi aşılanmış üç farklı anacın, açıkta ve örtü altında tüplü fidan üretiminin fidan randımanına etkisi (\%).

Table 22. The effect of tube saplings of graft combinations belonging to cabernet sauvignon grape variety with three american rootstocks under greenhouse and open field conditions on sapling performance (\%).

\begin{tabular}{ccccccc}
\cline { 2 - 7 } & \multicolumn{3}{c}{ 1.yıl } & \multicolumn{3}{c}{2 yıl } \\
\cline { 2 - 7 } & Açıkta & Örtü Altı & $\begin{array}{c}\text { Ortam } \\
\text { Ort. }\end{array}$ & Açıta & Örtü Altı & $\begin{array}{c}\text { Ortam } \\
\text { Ort. }\end{array}$ \\
\hline $99 \mathrm{R}$ & 78,57 & 84,12 & $81,35 \mathbf{b}$ & 26,67 & 20,00 & $23,34 \mathbf{b}$ \\
$110 \mathrm{R}$ & 46,03 & 60,32 & $53,18 \mathbf{c}$ & 23,33 & 32,50 & $27,92 \mathbf{b}$ \\
$1103 \mathrm{P}$ & 90,48 & 89,68 & $90,08 \mathbf{a}$ & 70,83 & 55,83 & $63,33 \mathbf{a}$ \\
\hline Anaç Ort. & $71,69 \mathbf{b}$ & $78,04 \mathbf{a}$ & & 40,28 & 36,11 & \\
\hline
\end{tabular}

Ortam 1.yıl LSD \%5:5, 124 ,Anaç 1.yıl LSD \%5:6,276, Ortam 2.yıl LSD \%5: ö.d., Anaç 2.yıl LSD \%1:18,444

\section{SONUÇ}

Çalışmada örtü altı ve açıkta yetiştiricilik şartlarında vegetasyon periyodu boyunca yetiştirilen, üç farklı Amerikan asma anacına Cabernet Sauvignon aşılı tüplü fidanların randıman ve kalite kriterleri açısından değerlendirmeler yapılmıştır.

Sera ve açıkta yetiştiricilik şartları arasındaki en önemli farklılıklar sürgün gelişme düzeyi, aşı sürgünü odunlaşma düzeyi ve fidan randımanı konularında olup her üç kriter için tüm aşı kombinasyonlarında örtü altında yapılan üretimin daha başarılı sonuçlar verdiği görülmüştür.

\section{KAYNAKLAR}

Açıkgöz, N., M.E. Akbaş, A. Moghaddam, K. Özcan, 1994. PC’ler İçin Veritabanı Esaslı Türkçe İstatistik Paketi: TARIST, 1.Tarla Bitkileri Kongresi, 24- 28.04.1994, Ege Üniversitesi Ziraat Fakültesi Ofset Basımevi, Bornova, İzmir, s:264-267

Anonim, “TS 3981 Asma Fidanı” TSE-Ankara (1995) 10s.

Baydar, N. G., Ece, M. 2005. Isparta Koşullarında Aşılı Asma Fidanı Üretiminde Farklı Çeşit/Anaç Kombinasyonlarının Karşılaştırılması. SDÜ Fen Bilimleri Enstitüsü Dergisi, 9(3).

Çelik, H., 1978. Asma Çeliklerinde Bazı Teknik ve Hormonal Uygulamaların Kallus Oluşumu, Aşı Tutma ve Köklenme Oranına Etkileri Üzerinde Araştırmalar. Ankara Üniversitesi Ziraat Fak. Bahçe Bitkileri Bölümü (Basılmamış Doktora Tezi), 128 s.

Çelik, H., 1982. Kalecik Karası/41B Aşı Kombinasyonu İçin Sera Koşullarında Yapılan Aşılı Köklü Fidan Üretiminde Değişik Köklenme Ortamları ve NAA Uygulamalarının Etkileri. Ankara Üniversitesi Ziraat Fak. Bahçe Bitkileri Bölümü. Ankara.

Çelik, H., 1984. Türkiye Bağcılığında Fidan Sorunu. Tokat Bağcılık Sempozyumu. 50-61, 25-28 Eylül 1984, Tokat.

Çelik, H., Çelik, M., ve A. Eriş, 1991. Farklı Dikim Şekilleri ve Köklendirme Ortamlarının Aşılı Asma Fidanı Üretiminde Başarılı Üzerine Etkileri. T.C. Tarım ve Köyişleri Bakanlığı Türkiye 1. Fidancılık Sempozyumu. 107-111, 1991, Ankara

Çelik, S. ve S. Gider, 1991. Bağ Kurmak Amacıyla Dikilen Köklü Anaçların Aynı Yıl İçinde Aşılanması. T.C. Tarım ve Köyişleri
Aşılı asma fidanı üretimi ile ilgili iki yıl ya da daha uzun süreli çalışmalarda yıl faktörünün önemli olabileceğine değinen ve buna yıllar arasındaki ekolojik farklılıkları sebep gösteren Samancı ve Uslu (1992)'nun da belirttiği gibi çalışmamızın bazı kriterlerine ait değerler de yıl faktöründen etkilenmiş ancak normal kabul edilebilecek bu durum yıllar arasında değerlerdeki paralelliği bozmamıştır.

Anaçlar açısından yapılacak değerlendirmede aşılı çubukların oluşturduğu köklenmeye ait kriterlerden; kök sayısında ve kök gelişim düzeylerinde en başarılı anaç olarak 1103P görülmüştür. Aşı sürgünü ile ilgili olarak $1103 \mathrm{P}$ anacı aşı sürgünü uzunluğu ve aşı sürgünü odunlaşmış kısım uzunluğu kriterlerinde öne çıkmıştır. Fidan değerlendirme kriterleri birlikte yorumlandığında $110 \mathrm{R}$ ve $99 \mathrm{R}$ anaçları birbirlerine çok yakın sonuçlar vermiş, kendi aralarında farklı kriterler açısından ikinci ve üçüncü olurlarken hiçbir kriter için açıkta veya örtü altı koşullarında $1103 \mathrm{P}$ anacını istatistikçe anlamlı olarak geçememişlerdir. Fidan randımanı açısından her iki yılın ayrı ayrı değerlendirilmesiyle oluşan sıralama, her iki yıl birlikte değerlendirildiğinde de korunmuş ve; 1103P anacı açıkta \%80.65, örtü altında \%72.75 ile en yüksek randıman değerine ulaşmıştır.

Bakanlığı Türkiye 1. Fidancılık Sempozyumu. 113-121, 1991, Ankara.

Çelik, S., Delice, A. ve L. Arın, 1992. Fidanlık Koşullarında Aşı1ı Köklü Asma Fidanı Üretimi. Doğa-Tr. J. of Agricultural and Foresty 16 (1992), 507-518.

Çelik, S., 1993. Bağcılık Tekniği I. Trakya Üniversitesi Tekirdağ Ziraat Fak. Yayınları:166, Ders Notu:76, Tekirdağ.

Çelik,H., Marasalı,B., Söylemezoğlu,G., Göktürk,N., Ergül,A., Patlak,H. 1995. Bağda uygulanan farklı aşılama yöntemlerinin aşıda başarı üzerine etkileri. Türkiye II. Ulusal Bahçe Bitkileri Kongresi Bildirileri Cilt II:480-484, 3-6 Ekim 1995, Adana.

Çelik. H., Ağaoğlu, Y.S., Fidan, Y., Marasalı, B., Söylemezoğlu, G. 1998. Genel Bağcılık, Sunfidan A.Ş. Mesleki Kitaplar Serisi: 1, Ankara, 1998, s.27.

Çelik,H., Kunter,B., Söylemezoğlu,G., Ergül,A., Çelik,H., Karataş,H., Özdemir,G., Atak,A. 2010. Bağcllğın geliştirilmesi yöntemleri ve üretim hedefleri. TMMOB ZMO Ziraat Mühendisliği VII. Teknik Kongresi Bildiriler Kitabı Cilt 1:493 513, 11-15 Ocak 2010, Ankara.

Dimler, R.J., Sheater, N.C. and C. Christ, 1952. Quantative Paper Chromatography of D-Glucose and It's Oligosaccarites Anat. Chem. 24: 1411-1514

Ecevit, F.M., 1991. Sağlıksız Fidan Dağıtımı ve Kurucuova (Beyşehir) Bağcılığının Sonu. T.C. Tarım ve Köyişleri Bakanlığı Türkiye 1. Fidancilik Sempozyumu. 149-152, 1991, Ankara. 
Ergenoğlu, F. ve S. Gürsoy, 1991. Akdeniz Bölgesi Bağcılığının Fidan Sorunu. T.C. Tarım ve Köyișleri Bakanlığı Türkiye 1. Fidancılık Sempozyumu. 85-95, 1991, Ankara

Eroğlu D., (Tez Danışmanı: Yrd. Doç. Dr. Mustafa ÇELIKK) "Bazı üzüm çeşitlerinin aşılı tüplü fidan üretimlerinde farklı biyolojik preparat uygulamalarının etkileri”Adnan Menderes Üniversitesi Fen Bilimleri Enstitüsü, Yüksek Lisans Tezi AYDIN.

Fidan, Y. ve A. Eriş, 1972. Bazı Önemli Sofralık ve Şaraplık Üzüm Çeşitlerinde Bir Senelik Dalların Özellikleri Üzerinde Araştırmalar. Ankara Üniversitesi Ziraat Fak. Yıllığı Yıl:22, Fasikül:3-4, 1972. Ankara

İlter, E., Kısmalı, İ, Atilla, A. ve İ. Uzun, 1984. Asma Fidanı Sorunu ve Çözümü İçin Öneriler. Türkiye II. Bağcıllk ve Şarapçıllk Sempozyumu. Bağcılık Araştırma Enstitüsü Müdürlüğü, Manisa 1984.

Kacar, B., 1972a. Bitki ve Toprağın Kimyasal Analizleri: I. Genel Bilgiler. Ankara Üniversitesi Ziraat Fak. Yayınları: 468, Yardımcı Ders Kitabı: 161, 151s. Ankara

Kacar, B., 1972b. Bitki ve Toprağın Kimyasal Analizleri: II. Bitki Analizleri Ankara Üniversitesi Ziraat Fak. Yayınları: 453, Uygulama Kilavuzu:155, 646s, Ankara.

Kara, Z., Söylemezoğlu, G., Çakır, A., Sabır, A., Shidfar, M., Aşılı Asma Fidanı Üretiminde Mikorizal Preparasyon (MP, Biovam) Uygulamalarının Etkileri, Türkiye VI. Ulusal Bahçe Bitkileri Kongresi. Harran Üniversitesi, Şanlıurfa 2011

Kaşka, N., Yılmaz, M., 1974. (Hartmann H.T. ve D.E. Kester' den çeviri) Bahçe Bitkileri Yetiştirme Tekniği, Ç.Ü. Ziraat Fakültesi Yayınları : 79, Adana
Kısmalı, I., 1978, Yuvarlak Çekirdeksiz Üzüm Çeşidi ve Farklı Amerikan Asma Anaçları ile Yapılan Aşıı Köklü Asma Fidanı Üzerinde Araştırmalar. Ege Üniversitesi Ziraat Fak. Bahçe Bitkileri Bölümü (Basılmamış Doçentlik Tezi), 120s.

Kısmalı, İ. ve N. Karakır, 1990. Asma Fidanı Elde Edilmesinde Kalite ve Randıman Arttırma Olanakları Üzerinde Araştırmalar. Doğa, Tarım ve Ormancıtık Dergisi, 14; 107-115.

Köse, B., Çelik, H., Karabulut, B. 2015. Determination of callusing performance and vine sapling characteristics on different rootstocks of'Merzifon Karasi'grape variety (Vitis vinifera L.). Anadolu Tarim Bilimleri Dergisi, 30(2), 87.

Neshev, K. and Todor, K.H. 1978. Use of Romanian paraffin mixture in the production of grapevine planting material. Hort.Abst. 49(6): 4120

Richards, M. 1976. Propagation of grapes by grafting. Plant Propagator $22(1): 8-10$.

Samancı, H., Uslu, İ. 1992 Aşılı-Köklü Asma Fidanı Üretiminde Randıman ve Kalitenin Çeşit Anaç Kombinasyonlarına Göre Değişiminin Araştırılması. Sonuç Raporu, Alata Bahçe Kültürleri Araştırma Enstitüsü 1992.

Sucu, S. 2012. (Tez Danışmanı: Yrd. Doç. Dr. Adem YAĞCI) Aşılama Öncesi Amerikan Asma Anaçlarına Ön Bekletme Uygulamalarının Fidan Randımanı Üzerine Etkileri GOÜ Fen Bilimleri Enstitüsü Yüksek Lisans Tezi, Tokat

Winkler, A. J. Et al., 1974, General Viticulture. Univ. Of Calif. Pres. London, $710 \mathrm{~s}$. 